\title{
Anti-allergic effects of onion, apple, cucumber, ginger, and broccoli mixtures and their bioactive compounds in RBL-2H3 cells
}

\author{
Mi Ja Chung ${ }^{1 *}$, Sanghyun Lee ${ }^{2}$, Deok Soon $\mathrm{Kim}^{3}$ \\ ${ }^{1}$ Department of Food Science and Nutrition, Gwangju University, Gwangju 61743, Korea \\ ${ }^{2}$ Department of Plant Science and Technology, Chung-Ang University, Anseong 17546, Korea \\ ${ }^{3}$ BeolgyoKKomak Co., Ltd., Boseong 59420, Korea
}

\section{양파, 사과, 오이, 생강, 브로콜리 혼합물들 및 이들에 함유된 생리활성 물질의 RBL-2H3 세포에서 알레르기 반응 저해효과}

\author{
정미자 ${ }^{*} \cdot$ 이상현 $^{2} \cdot$ 김덕순 $^{3}$ \\ 1광주대학교 식품영양학과, ${ }^{2}$ 중앙대학교 식물생명공학과, ${ }^{3}$ 벌교꼬막
}

\begin{abstract}
We investigated the anti-allergic effects of onion, apple, cucumber, ginger, and broccoli mixtures and their bioactive compounds on immunoglobulin $\mathbf{E}$ (IgE)-antigen complex-mediated allergic responses in rat basophilic leukemia (RBL)-2H3 cells. Cell viability, formation of reactive oxygen species (ROS), $\beta$-hexosaminidase release, and cytokine production were determined using 3-(4,5-dimethylthiazol-2-yl)-2,5-diphenyl tetrazolium bromide assay, 2,7dichlorofluorescein diacetate assay, $\beta$-hexosaminidase assay, and enzyme-linked immunosorbent assay, respectively. Ethanol extracts of onion, apple, cucumber, ginger, and broccoli inhibited the release of $\beta$-hexosaminidase in IgE-antigen complex-stimulated RBL-2H3 cells. Plant mixtures $(1,2$, and 3) containing different ratios of onion, apple, cucumber, ginger, and broccoli were prepared. The extracts of these mixtures also inhibited the release of IgE-antigen complex-stimulated $\beta$-hexosaminidase. High-performance liquid chromatography identified that the main bioactive compounds constituting these extracts were fisetin (Fis), kaempferol (Kae), isoquercitrin and spiraeoside. Fis and Kae dose-dependently inhibited the increase in ROS and $\beta$-hexosaminidase levels in IgE-antigen complex-stimulated RBL-2H3 cells. Additionally, Fis and Kae significantly attenuated the production of IgE-mediated pro-inflammatory cytokines, such as interleukin (IL)-4, IL-13, and tumor necrosis factor-alpha. Therefore, mixtures containing Fis and Kae may be used to develop anti-allergic functional foods.
\end{abstract}

Key words : anti-allergic effects, cytokines, $\beta$-hexosaminidase, IgE-antigen complex, RBL-2H3 cells

서 론

알레르기(allergy)란 생체 내에서 이물질이 방어기능을 가 지기 위하여 항원에 대한 항체가 생성되는데 다시 항원이 체 내에 들어왔을 때 항원과 항체가 복합체를 형성하여 과민 반
응을 유도하는 병적 현상을 의미한다(Leung 등, 2004). 즉, 외부 알레르기 원인 물질이 체내 침입 시 $\mathrm{Th} 1$ 과 $\mathrm{Th} 2$ cytokine 간 균형의 붕괴로 Interleukin(IL)-4, 5, 6 그리고 13 등과 같은 Th2 cytokine이 과잉 생산되고, B cello이 자극되어 immunoglobulin $\mathrm{E}(\mathrm{IgE})$ 가 생성된다(Chung 등, 2011). $\mathrm{IgE}$ 는

*Corresponding author. E-mail : mijachung@gwangju.ac.kr, Phone : +82-62-670-2049, Fax : +82-62-670-2062

Received 12 October 2020; Revised 31 October 2020; Accepted 02 November 2020.

Copyright (c) The Korean Society of Food Preservation.

This is an Open Access article distributed under the terms of the Creative Commons Attribution Non-Commercial License (http://creativecommons.org/licenses/by-nc/4.0) which permits unrestricted non-commercial use, distribution, and reproduction in any medium, provided the original work is properly cited. 
비만세포(mast cells) 또는 호염기구(basophil) 표면이 있는 $\mathrm{Fc}$ epsilon receptor 1(Fce RI) 수용체에 교차 결합하여(crosslinked) 동일한 알레르겐(항원)에 반복으로 노출될 경우 알레 르겐과 FceRI 수용체에 붙어 있는 고친화성(high-affinity) $\mathrm{IgE}$ 가 결합하여 복합체를 형성하여 비만세포 또는 호염기구 를 감작시키고 이들 세포들은 세포 내 저장된 histamine, $\beta$ hexosaminidase 등의 과립 화학물질의 탈과립 현상이 일어 난다. 이러한 탈과립 물질들이 원인으로 작용하여 알레르기 증상을 유발 및 악화시킨다(Kang 등 2020; Leung 등, 2004).

식품 알레르기(food allergy)는 달걀, 땅콩, 조개류 등 특 정 음식을 먹었을 때 알레르기 반응을 보이는 것으로 흔한 질병으로 무해한 특정 음식에 대해 우리 몸의 면역체계가 체내 유해한 것으로 판단하여 이를 삼켰을 때 비정상 혹은 부적절하게 과민 반응을 나타내는 것이다. 식품 알레르기는 아토피 피부염, 천식, 두드러기, 소화기 증상, 아나필락시스 등 다양한 알레르기 증상을 유발할 수 있다. 어릴 때부터 먹 어온 음식인데 어른이 되어 알레르기 반응이 나타날 수도 있다. 이러한 알레르기 반응은 원인과 형태가 다양해 유발 식품을 피하는 것이 가장 널리 알려져 있는 예방법이지만, 그 외에 알레르기 반응을 저감화시킬 수 있는 다양한 방법 들이 연구되고 있다(Chung 등, 2012; Chung 등, 2013; Kang 등, 2020).

알레르기 증상 유발 및 악화시키는 원인이 되는 비만세포 및 호염기구 탈과립화 및 Th2 cytokine 분비를 검정콩 껍질 유래 안토시아닌, 다양한 플라보노이드(flavonoids), 키토산 (chitosan) 등 천연소재들이 억제시켜 알레르기 증상을 완화 시킨다는 연구보고들이 있다(Chung 등, 2011; Chung 등, 2012; Chung 등, 2013).

본 연구의 최종 목적은 맛 좋고 알레르기 저감화 효과를 가진 가공식품을 개발하는 것이다. 따라서 항알레르기 효과 를 가진 천연소재들을 스크리닝 한 결과, 탈과립화 억제 효과 를 가진 양파, 사과, 오이, 생강 그리고 브로콜리를 선택하여 몇 종류의 혼합물들을 제조하였고, 최종적으로 최적배합비를 가진 혼합물 추출물을 이용하여 알레르기가 저감화된 가공식 품을 개발하고자 한다. 이와 같은 최종 목적을 달성하기 위해 본 연구에서는 호염기구에서 탈과립화 억제 효과를 가진 양 파, 사과, 오이, 생강 및 브로콜리 함유 식물 혼합추출물 3종 류를 선정하여 항알레르기 효과를 알아보았고, 이들 식물 혼 합추출물에 주요 성분을 HPLC로 분석한 후, 주요 성분 중 fisetin와 kaemferol의 ROS 생성 감소 및 항알레르기 효과를 알아보았다. 본 연구를 통하여 개발된 식물 혼합추출물이 알 레르기 저감화 제품 개발에 활용할 수 있는 과학적 근거 자료 로 활용하고자 한다.

\section{재료 및 방법}

\section{실험재료 및 추출물 제조}

양파(onion), 사과(apple), 오이(cucumber), 생강(ginger) 그리고 브로콜리(broccoli)는 2020년 5월 광주광역시 남구 대 형 마트에서 국내산으로 구입하여 양파는 껍질을 제거하고 다른 재료는 껍질을 제거하지 않은 채 흐르는 물에 깨끗이 씻은 후 물기를 제거하고, $50^{\circ} \mathrm{C}$ 에서 건조 및 분쇄한 분말을 추출물 제조에 사용하였다. 이들 분말을 이용하여 Table 1과 같이 양파, 사과, 오이, 생강, 브로콜리 혼합물들을 제조하였 다. 양파, 사과, 오이, 브로콜리, 생강 분말 시료는 중량의 20 배인 증류수 또는 10배의 주정(95\%; Woori Ethanol Supplies Co., Busan, Korea)을 넣었다. 더하여 mixture 1과 mixture 3 은 20 배의 증류수를 mixture 2 는 10 배의 주정을 넣은 후 6 $0^{\circ} \mathrm{C}$ 와 $60 \mathrm{rpm}$ 으로 맞추어진 shaking incubator(JSSI-100C, JSR, Seoul, Korea)에서 24시간 추출하였다. 추출한 것을 Whatman filter paper No.2(Whatman International Ltd., Springfield Mill, Kent, UK)를 사용하여 여과하였다. 여과한 추출물은 감암농축기(R-100, BüCHI, Flawil, Switzerland)를 사용하여 추출 용매를 제거한 후 동결건조기(Clean vac 8 , Hanil, Incheon, Korea)로 동결건조한 분말은 $-20^{\circ} \mathrm{C}$ 에 보관하 면서 실험에 사용하였다. 수율은 추출물에 사용된 분말 시료 에 대한 동결건조 분말을 백분율로 나타내었다.

\section{추출물에 함유된 플라보노이드 함량 분석}

동결건조 분말을 $40 \mathrm{mg}$ 을 취한 후 $100 \% \mathrm{MeOH}$ 에 용해 하여 $40 \mathrm{mg} / \mathrm{mL}$ 로 조제한 후 $(4,000 \mathrm{rpm})$ 초음파 진탕기로 20 분간 녹인 후 $0.45 \mu \mathrm{m}$ PVDF 멤브레인 필터(Whatman, Maidstone, UK)로 여과하여 시험용액으로 사용하였다. 분석 에 사용된 HPLC system은 binary pump(Waters 1525, Waters Inc., Milford, MA, USA)와 UV-Visible detector (Waters 2489, Waters Inc.)가 장착된 것으로 분석하였다. 컬 럼은 YMC-Pack Pro $\mathrm{C}_{18}$ column $(25 \mathrm{~cm} \times 4.6 \mathrm{~mm}, 5 \mu \mathrm{m})$ (Waters Inc.)을 사용하여 분리를 진행하였다. 3 차 증류수와

Table 1. The ratio of mixtures containing onion, apple, cucumber, ginger, and broccoli

\begin{tabular}{cl}
\hline Mixtures & \multicolumn{1}{c}{ Mixing ratio $(\mathrm{w} / \mathrm{w})$} \\
\hline Mixture 1 & Onion $:$ apple $:$ cucumber $:$ ginger $:$ broccoli \\
& $=1: 2: 1: 0.5: 1$ \\
Mixture 2 & $\begin{array}{l}\text { Onion }: \text { apple }: \text { cucumber }: \text { ginger }: \text { broccoli } \\
=1: 1: 1: 1: 1\end{array}$ \\
Mixture 3 & Onion $:$ apple $:$ cucumber $:$ ginger $:$ broccoli \\
& $=2: 2: 1: 0.5: 1$
\end{tabular}


acetonitrile을 이동상으로 83:17 비율로 시작하여 10분 후 $70: 30$ 비율로 15 분간 기울기 용리한 다음 $20: 80$ 비율로 5 분 후 기울기 용리로 흘려 준 후 최종 acetonitrile $100 \%$ 로 5 분간 유지하였다. 시료는 $20 \mu \mathrm{L}$ 를 주입하였고, 유속은 $1.0 \mathrm{~mL} / \mathrm{min}$ 으로 설정하였으며, 모든 피크는 $360 \mathrm{~nm}$ 의 파장을 이용하여 검출하였다. 이동상을 사용하기 전에 $0.45 \mu \mathrm{m}$ 필터(Millipore, Milford, MA, USA)를 통해 여과하고, 진공 하에 탈기하여 사용하였다.

\section{세포 배양}

RBL-2H3 세포는 Korea Cell Line Bank(Seoul, Korea)에 서 구입하여 $10 \%$ fetal bovine serum(FBS; WelGene Co., Daegu, Korea) 및 $1 \%$ penicillin과 streptomycin(PEST; WelGene Co.) 용액을 함유한 Eagle's minimum essential medium(MEM; WelGene Co.) 배양액으로 $5 \% \mathrm{CO}_{2}$ 가 공급 되는 배양기에서 $37^{\circ} \mathrm{C}$ 조건으로 배양하였다.

\section{세포 생존율 측정}

RBL-2H3 세포는 96-well plates에 $1 \times 10^{4}$ cell $/ \mathrm{mL}$ 의 세포 수로 분주하여 24시간 배양하였다. 2시간 기아상태를 유지시 킨 후 시료를 $\mathrm{FBS}$ 가 첨가되지 않은 MEM으로 시료를 농도별 로 만들 후 세포에 처리하였다. 24시간 배양 후 세포 생존율은 Jeong 등(2019)의 방법과 유사하게 3-(4,5-dimethylthiazol2-yl)-2,5-diphenyltetrazolium bromide(MTT, Sigma-Aldrich Co., St. Louis, MO, USA) 환원 방법을 이용하여 측정하였 다. 즉, 각 well에 MTT 용액 $(5 \mathrm{mg} / \mathrm{mL})$ 을 성장배지의 10 분의 1 을 가해주고, 다시 $37^{\circ} \mathrm{C}$ 에서 4 시간 더 배양하여 MTT를 환 원시켜 생성된 formazan이 배지에 따라 나가지 않도록 배지 를 조심스럽게 제거하였다. 남아있는 배지를 완전히 제거하 기 위해 실온에서 30 분간 방치한 후 dimethyl sulfoxide (DMSO, Sigma-Aldrich Co.)를 이용하여 용해시킨 시료를 $570 \mathrm{~nm}$ 에서 흡광도를 측정하였다. 흡광도 측정 시 공시료는 $\mathrm{DMSO}$ 로 하였고, 세포의 생존율은 아래와 같이 계산하였다.

$$
\text { 세포 생존율 }(\%)=\frac{\text { 시료 처리군의 흡광도 }}{\text { 대조군의 흡광도 }} \times 100
$$

\section{세포 내 ROS 측정}

세포 내 활성 산소종(reactive oxygen species, ROS)의 양 을 측정하는 방법으로 ROS 수준은 2,7-dichlorofluorescindiacetate(DCF-DA; Molecular Probes, OR, USA) probe를 이용 하여 측정하였다(Chung 등, 2013; Han 등, 2011). RBL-2H3 세포는 96-well plates에 $2 \times 10^{5} \mathrm{cell} / \mathrm{mL}$ 의 세포수로 분주하여 24 시간 배양하였다. 2 시간 $\mathrm{FBS}$ 가 함유되지 않은 $1 \% \mathrm{PEST}$
가 함유된 MEM 배지로 기아상태를 유지한 후, anti-dinitrophenol(DNP) monoclonal $\operatorname{IgE}(0.5 \mu \mathrm{g} / \mathrm{mL}$; Sigma-Aldrich Co. $)$ 을 함유한 $\mathrm{MEM}(1 \%$ PEST)에 24시간 배양하였다. Siraganian buffer 1(pH 7.2, $119 \mathrm{mM} \mathrm{NaCl}, 5 \mathrm{mM} \mathrm{KCl}, 0.4 \mathrm{mM} \mathrm{MgCl}$, $25 \mathrm{mM}$ PIPES)로 세포를 2번 세척하였고, Siraganian buffer $2(\mathrm{pH} 7.2,119 \mathrm{mM} \mathrm{NaCl}, 5 \mathrm{mM} \mathrm{KCl}, 0.4 \mathrm{mM} \mathrm{MgCl}, 25$ $\mathrm{mM}$ PIPES, $5.6 \mathrm{mM} \mathrm{CaCl}_{2}, 0.1 \% \mathrm{BSA}$ )을 넣은 후 10 분간 배양기에 두었다. Siraganian buffer 2 를 제거한 후 시료가 함 유된 $\mathrm{MEM}(1 \% \mathrm{PEST})$ 를 넣은 후 2시간 배양하였다. Siraganian buffer 1으로 3회 씻은 후 1시간 동안 $2 \mu \mathrm{g} / \mathrm{mL} \mathrm{DNP-}$ conjugated human serum albumin(DNP-HSA; Sigma-Aldrich Co.)를 처리하였다. $50 \mu \mathrm{M} \mathrm{DCF-DA}$ 를 함유한 PBS를 세포 에 처리한 후 $\mathrm{CO}_{2}$ 배양기에서 45 분 동안 배양한 후 $\mathrm{PBS}$ 로 두 번 씻는다. $\mathrm{PBS}$ 를 넣은 후 5 분 동안 $37^{\circ} \mathrm{C}$ 에 방치한 후 $\mathrm{DCF}$ 의 형광은 fluorometic microplate reader(BioTek, Winooski, VT, USA)로 파장 $495 \mathrm{~nm}$ (excitation)와 $525 \mathrm{~nm}$ (emission)에 서 측정하였다.

\section{$\boldsymbol{\beta}$-Hexosaminidase 활성 측정}

$\beta$-Hexosaminidase 방출 정도는 Chung 등(2013)의 방법을 일부 변경하여 측정하였다. 즉, 24-well plates에 RBL-2H3 세포 $\left(5 \times 10^{5} \mathrm{cell} / \mathrm{mL}\right)$ 를 48 시간 배양하였다. $\mathrm{FBS}$ 가 함유되지 않은 $1 \% \mathrm{PEST}$ 가 함유된 MEM 배지로 2시간 기아상태를 유 지한 후 $\operatorname{IgE}(0.5 \mu \mathrm{g} / \mathrm{mL}$; Sigma-Aldrich Co.)을 함유한 MEM ( $1 \%$ PEST)에 24시간 배양하였다. Siraganian buffer 1로 세 포를 2번 씻었고, Siraganian buffer 2 을 넣은 후 10 분간 배양 기에 방치 후 제거하였다. 그 다음 시료가 함유된 $\operatorname{MEM}(1 \%$ PEST)로 2시간 배양하였다. Siraganian buffer 1으로 3회 씻 은 후 2시간 동안 $10 \mu \mathrm{g} / \mathrm{mL}$ DNP-HSA(Sigma-Aldrich Co.) 를 처리하였다. 각 plate를 10 분간 ice bath에서 둠으로써 반응 을 종결시켰고, 96-well plate에 상층액 $30 \mu \mathrm{L}$ 와 substrate buffer[2 mM 4-p-nitrophenyl-N-acetyl- $\beta$-D-glucosaminide in $0.1 \mathrm{M}$ sodium citrate buffer( $\mathrm{pH} 4.5)] 30 \mu \mathrm{L}$ 를 넣어 섞은 후 $37^{\circ} \mathrm{C}$ 에서 1 시간 동안 반응시켰다. 반응 정지를 위해 $0.1 \mathrm{M}$ $\mathrm{Na}_{2} \mathrm{CO}_{3} / \mathrm{NaHCO}_{3}(\mathrm{pH} \quad 10.0)$ 용액 $200 \mu \mathrm{L}$ 를 더한 후 microplate reader (AMR-100, Allsheng Co., Ltd., Hangzhou, China)를 이용하여 $405 \mathrm{~nm}$ 에서 흡광도를 측정하였다.

\section{Cytokine 생성량 측정}

세포배양액 중 IL-4 그리고 Tumor necrosis factor(TNF)$\alpha$ (Abcam, Cambridge, UK), IL-13(RayBiotech, Norcross, GA, USA)는 ELISA kit을 이용하여 제조사 지침에 따라 microplate reader(AMR-100, Allsheng Co., Ltd., Hangzhou, China)로 측정하였다. 


\section{통계처리}

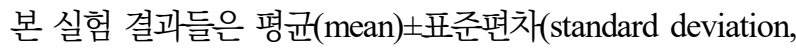
$\mathrm{SD}$ )로 표시하였고 실험군간 평균의 차이는 one-way ANOVA 로 유의성을 확인한 후 Duncan's multiple range test를 이용 하여 사후 검정하였으며 $\mathrm{p}<0.05$ 수준에서 유의성의 여부를 검증하였다. 모든 통계 분석은 SPSS(Statistical Package for the Social Science) version 17.0 프로그램(SPSS Inc., Chicago, IL, USA)을 이용하여 분석하였다.

\section{결과 및 고찰}

\section{양파, 사과, 오이, 생강, 브로콜리 및 이들 혼합물의 추출 수율}

천연물로부터 생리활성물질 등 유효 성분을 최대한 많이 얻을 수 있는 추출을 위해 추출 용매 사용량, 추출 용매의 종 류, 추출 온도와 시간 등이 검토되고 있다(Cha 등, 2006; Choi 등, 2000).

양파, 사과, 오이, 생강 및 브로콜리 열수 추출물과 주정 추출물의 수율은 Table 2 와 같다. 양파, 사과 및 브로콜리와 비교하여 오이와 생강의 수율이 낮았고, 생강은 열수 추출물 및 주정 추출물 모두 수율이 $15 \%$ 이하였다. 혼합물들 (mixtures)의 수율은 모두 30\%보다 높은 수율을 나타내었다.

Lee 등(2011)은 34종류의 산채류의 물 추출물 수율은

Table 2. Extract yield from onion, apple, cucumber, ginger, broccoli and their mixtures ${ }^{1)}(1,2$, and 3$)$

\begin{tabular}{ccc}
\hline Treatment & Sample & Yield (\%) \\
\hline Water & Onion & 40.2 \\
& Apple & 41.4 \\
& Cucumber & 24.2 \\
& Ginger & 12.4 \\
& Broccoli & 40.1 \\
\hline EtOH & Onion & 47.8 \\
& Apple & 38.6 \\
& Cucumber & 26.4 \\
& Ginger & 13.4 \\
& Broccoli & 35.2 \\
\hline Water & Mixture 1 & 36.9 \\
EtOH & Mixture 2 & 31.1 \\
Water & Mixture 3 & 36.5 \\
\hline
\end{tabular}

${ }^{1)}$ The explanation of mixtures are provided in Table 1 .
4.6-34.6\%였다고 하였는데, 본 연구에서 사용된 양파, 사과, 오이, 생강 및 브로콜리 열수 추출물 수율은 $12.4-41.4 \%$ 이었 고, 열수 추출물과 주정 추출물의 수율은 비슷하였다.

양파, 사과, 오이, 생강, 브로콜리 및 이들 혼합물의 세포독성

양파(onion), 사과(apple), 오이(cucumber), 생강(ginger), 브 로콜리(broccoli) 열수 추출물 및 주정 추출물을 $250 \mu \mathrm{g} / \mathrm{mL}$ 와 $500 \mu \mathrm{g} / \mathrm{mL}$ 를 RBL-2H3 세포에 24시간 처리한 결과 열수 추 출물은 모든 처리군에서 대조군과 비교하여 세포 독성이 없 었고(data not shown), 주정 추출물 역시 모든 처리군에서 대 조군과 비교하여 유의적 차이가 없었다(Fig. 1A).

Table 1에서 제시한 비율로 제조한 양파, 사과, 오이, 생강 및 브로콜리 혼합물 1(mixture 1) 열수 추출물(Mix 1), mixture 2 의 주정 추출물(Mix 2) 그리고 mixture 3 의 열수 추출물 (Mix 3)을 각각 100,250 그리고 $500 \mu \mathrm{g} / \mathrm{mL}$ 처리했을 때 $500 \mu \mathrm{g} / \mathrm{mL}$ Mix 2 처리군을 제외하고 대조군과 비교하여 세 포 생존율이 유의적 차이가 없었다. $500 \mu \mathrm{g} / \mathrm{mL}$ Mix 2 처리 군의 세포 생존율은 $76 \%$ 로 $24 \%$ 세포가 사멸하였으므로 세 포독성이 있다는 것을 알 수 있었다(Fig. 1B). 따라서 계속되 는 실험에서는 양파, 사과, 오이, 생강 및 브로콜리 주정 추출 물의 처리 농도는 0-500 $\mu \mathrm{g} / \mathrm{mL}$ 그리고 이들의 혼합물들(Mix $1, \operatorname{Mix} 2$ 그리고 Mix 3)의 추출물은 $0-250 \mu \mathrm{g} / \mathrm{mL}$ 까지로 정 하였다.

본 연구에서 혼합물들을 개발한 목적은 알레르겐(allergen) 를 함유한 식재료를 주원료로 하여 개발된 가공식품들로 인 한 알레르기 발생 위험을 줄이고자 알레르기 저감화 가공공 정을 개발하는 것이다. 더하여 개발된 제품이 소비자의 입맛 에 맞아야 한다. 따라서 양파, 사과, 오이, 생강 및 브로콜리 를 이용하여 5 종류의 배합비를 만들었고, 3 종류는 Table 1 과 같다. 다른 두 종류의 배합비는 양파, 사과, 오이, 생강 및 브 로콜리를 $1: 1: 1: 1: 1$ (기본 비율) 비율을 가진 배합비였는 데, 이들 열수 추출물의 관능검사 결과(결과 미제시) 단맛은 약간 있으나, 쓴향과 쓴맛이 느껴져 관능검사 점수가 낮았 다. 쓴향과 쓴맛을 줄이기 위해 생강의 비율을 1 에서 0.5 로 감소하였고, 단맛을 증가시키기 위해 사과의 비율은 1 에서 2로 조정하였다. 그 비율이 Table 1에 제시한 mixture 1이다. Mixture 1은 쓴맛과 쓴향도 줄어들고 단맛도 강화되었지만 $\beta$-hexosaminidase 방출 억제 효과가 뛰어난 생강을 줄이고, 효과가 약한 사과를 증가시켰으므로(Fig. 2) 항알레르기 효과 는 감소 되었다(data not shown). 따라서 맛도 좋으면서 항알 레르기 효과도 강한 배합비를 찾기 위해 강한 맛이 나지 않으 면서 $\beta$-hexosaminidase 방출 억제 효과가 뛰어난 양파의 비 율을 mixture 1 보다 증가시켜 mixture 3 을 개발하였다(Table 1). 양파의 비율을 증가시킨 결과 단맛은 증가하였고, 쓴맛과 
(A)

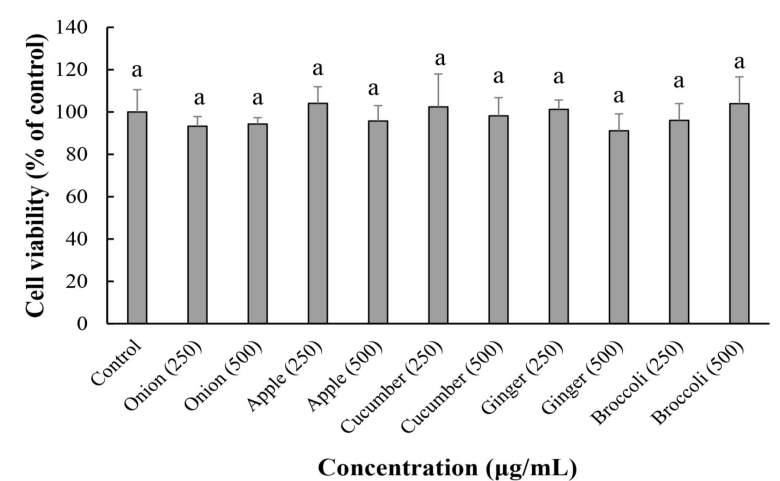

(B)

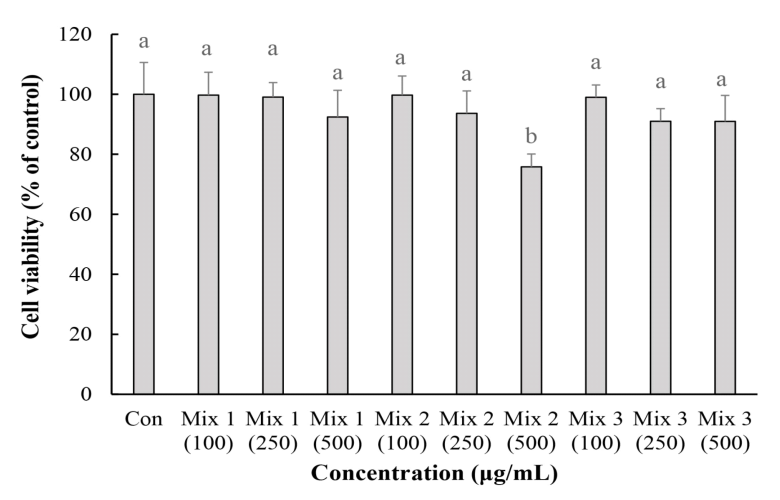

(C)

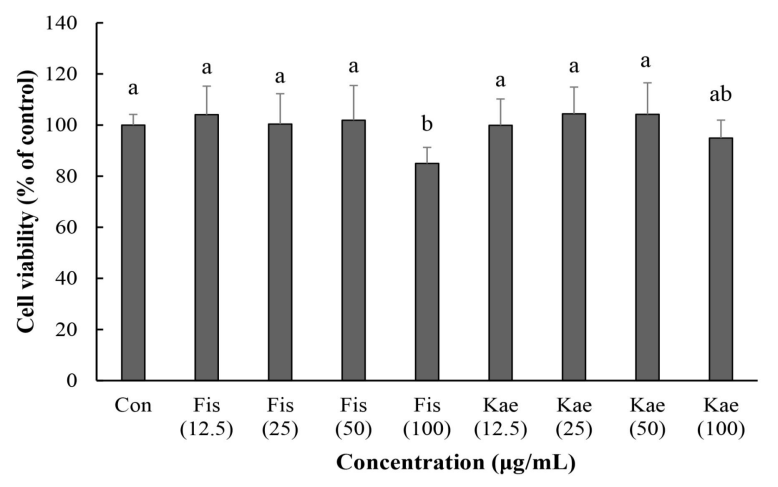

Fig. 1. Cytotoxicity of fisetin (Fis), kaempferol (Kae), extracts from onion, apple, cucumber, ginger, broccoli and their mixtures on RBL-2H3 cells.

The values are expressed as mean $\pm \mathrm{SD}(\mathrm{n}=8)$; means with different letters significantly differ from each other $(\mathrm{p}<0.05)$ as determined by Duncan's multiple range test. The explanation of mixtures are provided in Table 1. Mix 2 is ethanol extract of mixture 2. Mix 1 and Mix 3 were water extracts of mixture 1 and mixture 3 .

쓴향도 느껴지지 않아 개발된 배합비 중 종합적 기호도가 가 장 높은 배합비를 개발하였다. 양파, 사과, 오이, 생강, 브로콜 리 및 블루베리 $1: 1: 1: 1: 1: 1$ 배합비도 개발하였지만, 블루베리의 건조 및 분쇄에 대한 어려움 등을 고려하여 제외
하였다. 양파, 사과, 오이, 생강 및 브로콜리를 이용한 다양한 배합비의 주정 추출물들을 개발하였으나, 색깔 외 맛에 대한 관능검사가 불가능하여 색깔이 가장 우수한 기본 비율인 양 파, 사과, 오이, 생강 및 브로콜리의 $1: 1: 1: 1: 1$ 배합비를 가진 추출물을 본 연구에 사용하였다.

\section{양파, 사과, 오이, 생강, 브로콜리 및 이들 혼합물이 $\beta$ - hexosaminidase 방출에 미치는 영향}

$\mathrm{IgE}-$ 항원 복합체에 의해 감작된 RBL-2H3 세포에서 양파, 사과, 오이, 생강, 브로콜리 주정 추출물 $250 \mu \mathrm{g} / \mathrm{mL}$ 와 500 $\mu \mathrm{g} / \mathrm{mL}$ 가 $\beta$-hexosaminidase 방출에 미치는 영향은 Fig. $2 \mathrm{~A}$ 와 같다. $\mathrm{IgE}$ 감작 후 DNP-HSA 처리는 현저하게 $\beta$-hexosaminidase 방출을 증가시켰고, 이들 증가는 양파, 생강, 사과,

(A)

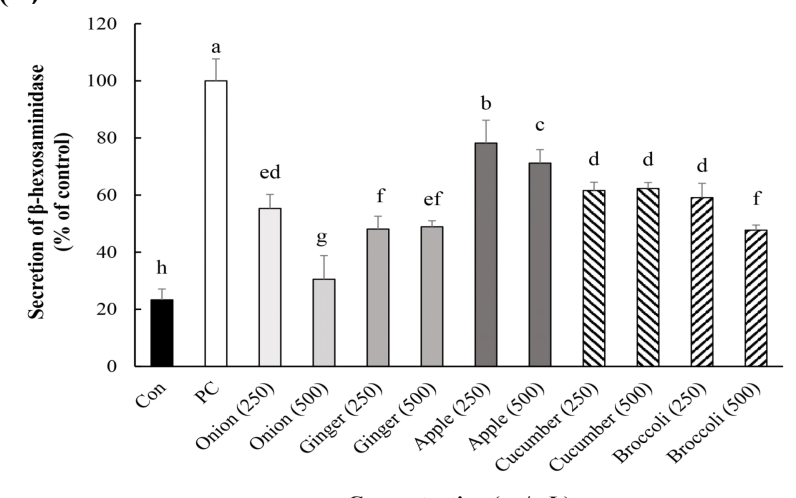

(B)

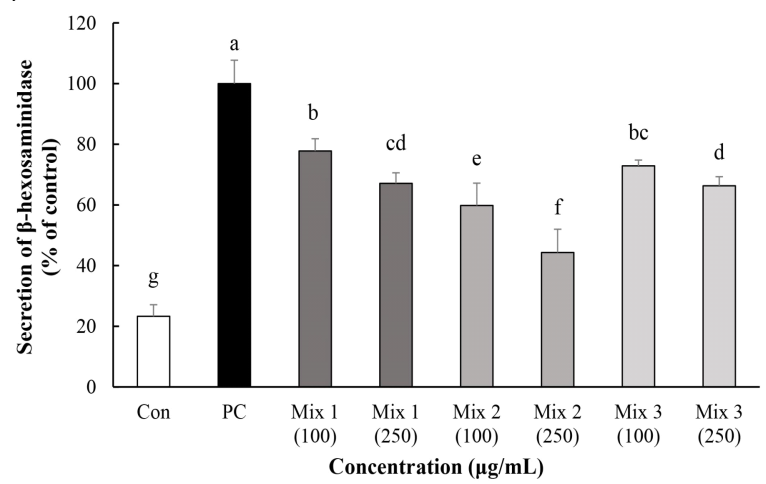

Fig. 2. Effects of onion, ginger, apple, cucumber, broccoli (A) and their mixtures (B) on $\beta$-hexosaminidase release in IgE-antigen complex-stimulated RBL-2H3 cells.

IgE-sensitized RBL-2H3 cells were pretreated with sample for $2 \mathrm{~h}$ prior to exposure to DNP-HSA $(10 \mu \mathrm{g} / \mathrm{mL})$ for $2 \mathrm{~h}$. Con (control), without IgE + DNP-HSA and sample; PC (positive control), IgE + DNP-HSA. The values are expressed as mean $\pm \mathrm{SD}(\mathrm{n}=4)$; means with different letters significantly differ from each other $(\mathrm{p}<0.05)$ as determined by Duncan's multiple range test. The explanation of mixtures are provided in Table 1. Mix 2 is ethanol extract of mixture 2. Mix 1 and Mix 3 were water extracts of mixture 1 and mixture 3 . 
오이 및 브로콜리 주정 추출물 처리에 의해 현저하게 감소하 였다. 양파와 생강 추출물이 사과 및 오이 추출물보다 더 효 과적으로 $\beta$-hexosaminidase 방출을 억제하였다. 양파, 사과, 오이, 생강, 브로콜리를 Table 1에서 제시한 비율의 혼합물들 (mixtures)을 제조하여 이들 혼합물로부터 추출물들(Mix 1, Mix 2 그리고 Mix 3)을 얻었다. RBL-2H3 세포 내 IgE-항원 복합체 형성으로 증가된 $\beta$-hexosaminidase 방출을 Mix 1, Mix 2 그리고 Mix 3 각각의 처리에 의해 현저하게 억제되었 고, 특히 $250 \mu \mathrm{g} / \mathrm{mL}$ Mix 2 처리는 양성 대조군(100\%)에 비 교하여 $\beta$-hexosaminidase 방출은 $44.3 \%$ 로 $55.7 \%$ 감소하였 다(Fig. 2B).

항알레르기 효과를 알아보기 위하여 IgE로 감작된 비만세 포에 항원을 처리하여 활성화된 비만세포에서 유리된 히스타 민 양을 측정하는 방법이 있으나, 비만세포(mast cells) 또는 호염기 세포(basophils)에서 히스타민 분비 농도는 매우 낮으 므로 세포 내 많이 함유되어 있고 히스타민과 함께 분비되는 $\beta$-hexosaminidase 활성을 측정함으로써 탈과립 정도를 알 수 있다(Chung 등, 2011; Wendeler과 Sandhoff, 2009).

RBL-2H3 세포에 쑥에서 분리된 eupatilin과 jaceoside 그 리고 검정콩 껍질 유리 안토시아닌 처리에 의해 IgE-항원 복
합체에 의해 유도된 $\beta$-hexosaminidase 방출이 억제되었다고 하였는데, 이들 연구들(Chung 등, 2011; Lee 등, 2007)은 본 연구 결과들과 유사한 경향을 나타내었다.

세포의 탈과립 정도를 알 수 있는 histamin과 $\beta$-hexosaminidase 방출 저해 효과를 가진 천연소재 발굴은 알레르기 반응을 유발할 수 있는 식재료로 제품을 개발할 때 알레르기 를 저감화할 수 있는 제품 개발에 활용할 수 있을 것이며, 신 약 개발, 건강기능식품 개발 등 다양한 분야에 활용할 수 있 을 것이다.

본 연구에서 개발한 혼합물들이 $\beta$-hexosaminidase 방출을 억제함으로써 항알레르기 효과가 있다는 것을 알 수 있었으 므로 이들 혼합물에 함유된 주요 물질들을 분석하여 보았다.

\section{양파, 사과, 오이, 생강, 브로콜리 혼합물의 주요 물질 분석}

Table 1에서 제시한 비율로 혼합한 혼합물 1(mixture 1), 혼합물 2 그리고 혼합물 3의 추출물들(Mix 1, Mix 2 그리고 Mix 3)에 함유된 fisetin, kaempferol, isoquercitrin 그리고 spiraeoside(Fig. 3)를 HPLC로 분석한 결과 Fig. 4, Fig. 5 그 리고 Table 3과 같다. Mix 2는 mixture 2의 주정 추출물이고, Mix 1과 Mix 3은 mixture 1과 3의 열수 추출물인데 Mix 2가
(A)<smiles>O=c1c(O)c(-c2ccc(O)c(O)c2)oc2cc(O)ccc12</smiles>

Fisetin<smiles>O=c1c(O[C@@H]2O[C@H](CO)[C@@H](O)[C@H](O)[C@H]2O)c(-c2ccc(O)c(O)c2)oc2cc(O)cc(O)c12</smiles>

Isoquercitrin (=quercetin 3-O-glucoside)
(B)<smiles>O=c1c(O)c(-c2ccc(O)cc2)oc2cc(O)cc(O)c12</smiles>

Kaempferol<smiles>O=c1c(O)c(-c2ccc(O[C@@H]3O[C@H](CO)[C@@H](O)[C@H](O)[C@H]3O)c(O)c2)oc2cc(O)cc(O)c12</smiles>

Spiraeoside

(=quercetin 4'-O-glucoside)

Fig. 3. Structures of fisetin, kaempferol, isoquercitrin, and spiraeoside. 
(A)

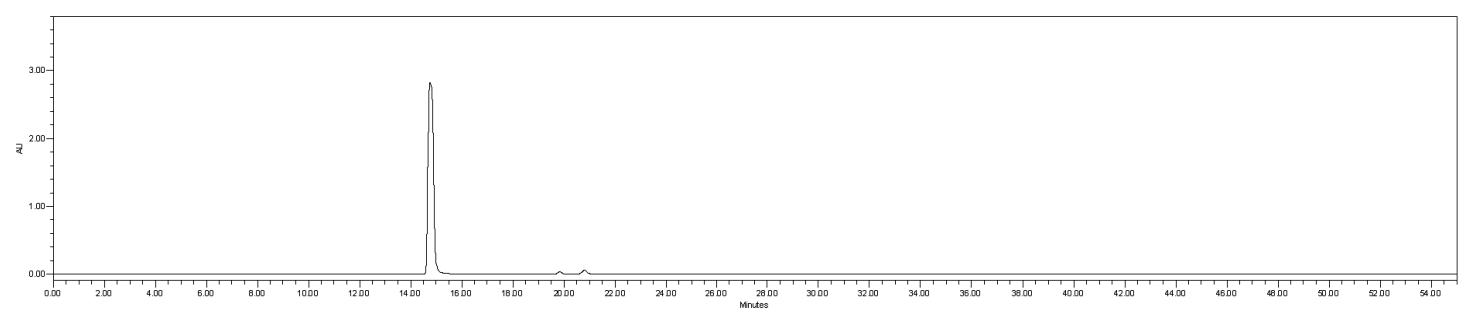

(B)

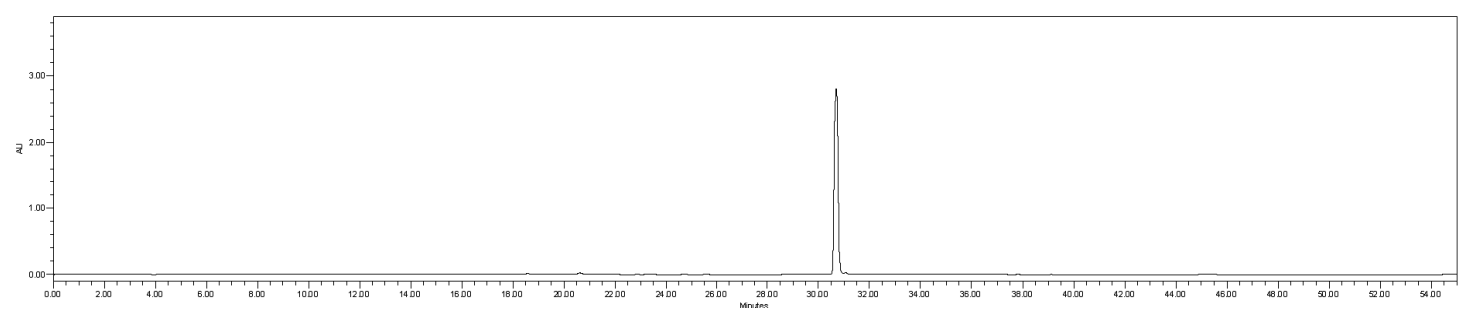

(C)

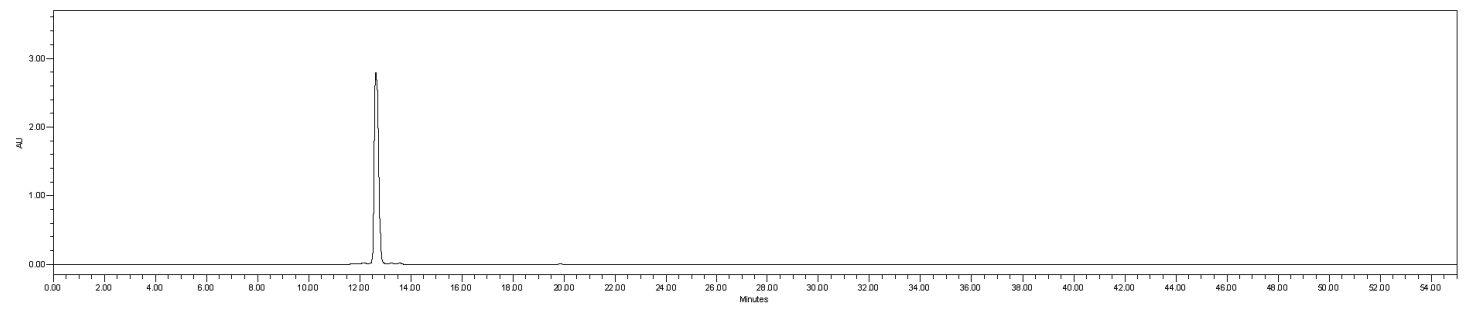

(D)

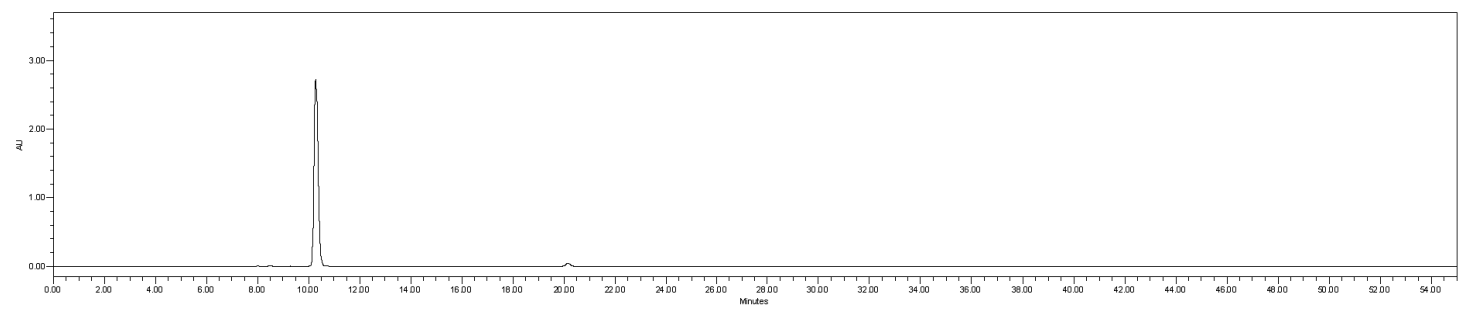

Fig. 4. HPLC-UV chromatograms on standards of fisetin (A), kaempferol (B), isoquercitrin (C), and spiraeoside (D).

다른 혼합물 추출물들보다 fisetin, kaempferol, isoquercitrin 및 spiraeoside 함량이 Mix 1보다 3.5-187배, Mix 3보다 4-66 배 더 높은 함량이 검출되었다. Mix 2가 다른 추출물보다 $\mathrm{IgE}+\mathrm{DNP}-\mathrm{HSA}$ 복합체에 의해 활성화 된 RBL-2H3 세포 내 탈과립화 증가를 효과적으로 억제하였는데, 이와 같은 결과 는 Mix 2에 다량 함유된 fisetin, kaempferol, isoquercitrin 그 리고 spiraeoside에 의한 영향일 수 있을 것이라 추정할 수 있었다.

RBL-2H3 세포에 isoquercitrin 처리는 $\beta$-hexosaminidase 분비와 Th2 cytokines 생성 억제 효과가 있었고(Hwang 등, 2018), spiraeoside 역시 RBL-2H3 세포에서 탈과립화를 억
제한다는 보고가 있어(Kim 등, 2015), 본 연구에서는 혼합물 의 주요 기능 성분 4종류 중에서 isoquercitrin과 spiraeoside 를 제외한 fisetin과 kaemferol 처리가 IgE-항원(DNP-HSA) 에 의해 활성화된 RBL-2H3 세포 내에서 ROS 생성, 탈과립 화 및 cytokines 생성에 미치는 영향을 알아보았다.

\section{Fisetin과 kaemferol이 세포독성 및 세포내 ROS 생성에 미치는 영향}

알레르기를 유발하는 식재료를 이용한 알레르기 저감화 제 품 개발을 위해 개발된 식물혼합물들(Mix 1, Mix 2, Mix 3)의 주요 생리활성 물질 중 하나인 fisetin과 kaemferol의 세포독성 
(A)

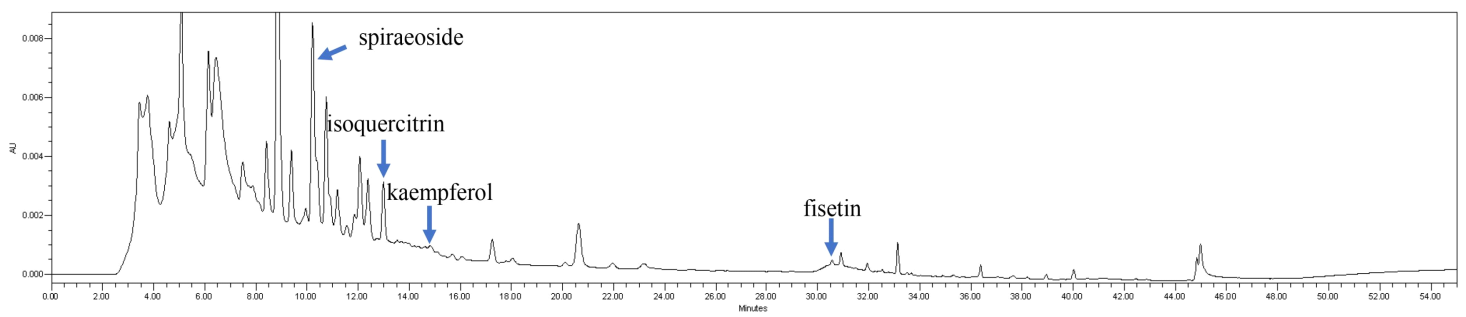

(B)

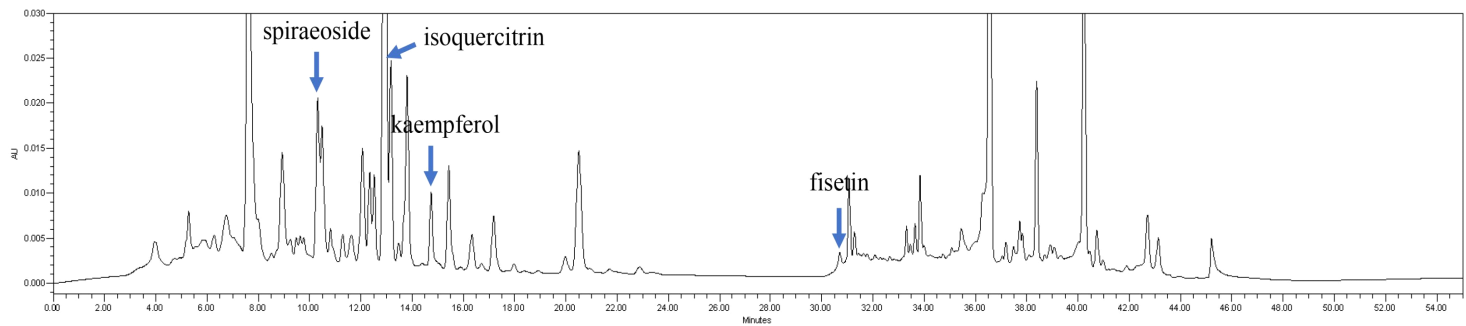

(C)

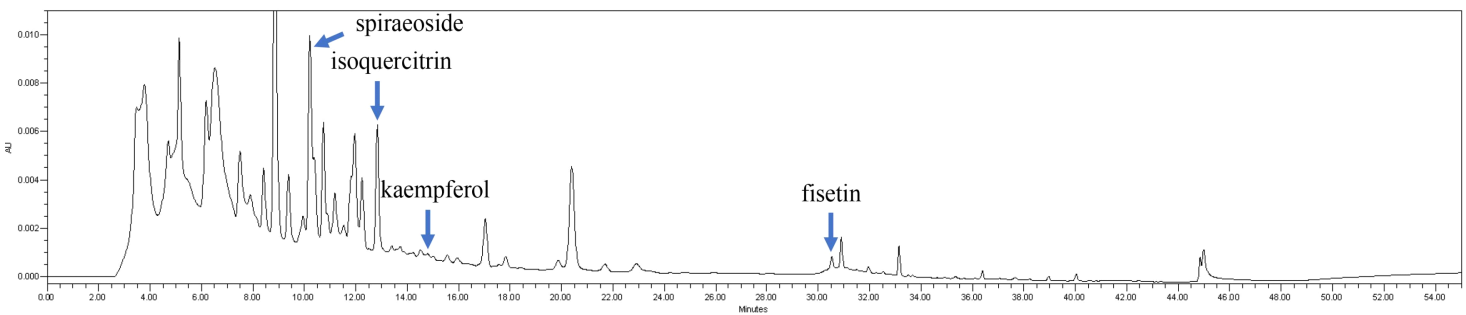

Fig. 5. HPLC-UV chromatograms of Mix 1 (A), Mix 2 (B), and Mix 3 (C).

Mix 2 is ethanol extract of mixture 2. Mix 1 and Mix 3 were water extracts of mixture 1 and mixture 3. The explanation of plant mixtures are provided in Table 1.

Table 3. The contents of fisetin, kaempferol, isoquercitrin, and spiraeoside in the extract from plant mixtures

\begin{tabular}{ccccc}
\hline & \multicolumn{4}{c}{ Contents $(\mu \mathrm{g} / \mathrm{g}$ extract) } \\
\cline { 2 - 5 } Samples $^{1)}$ & Fisetin & Kaempferol & Isoquercitrin & Spiraeoside \\
\hline Mix 1 & Trace & Trace & $8.0 \pm 0.0$ & $35.0 \pm 1.0$ \\
Mix 2 & $66.1 \pm 2.1$ & $19.0 \pm 1.0$ & $1,494.0 \pm 77.0$ & $124.0 \pm 3.0$ \\
Mix 3 & Trace & $2.1 \pm 0.0$ & $23.1 \pm 0.0$ & $31 \pm 1.0$ \\
\hline
\end{tabular}

${ }^{1)}$ The explanation of plant mixtures are provided in Table 1. Mix 2 is ethanol extract of mixture 2. Mix 1 and Mix 3 were water extracts of mixture 1 and mixture 3. Data are represented as mean $\pm \mathrm{SD}(\mathrm{n}=3)$ in $\mu \mathrm{g} / \mathrm{g}$ of extracts of samples.

을 알아본 결과는 Fig. 1 C와 같다. Fisetin 또는 kaemferol 12.5, 25,50 그리고 $100 \mu \mathrm{g} / \mathrm{mL}$ 를 각각 RBL-2H3에 24시간 처리한 결과, $100 \mu \mathrm{g} / \mathrm{mL}$ fisetin 처리군 외에는 세포독성이 나타나지 않았다. $100 \mu \mathrm{g} / \mathrm{mL}$ fisetin 처리군의 세포생존율은 $85 \%$ 로 약 한 독성이 있었으나, $100 \mu \mathrm{g} / \mathrm{mL}$ kaemferol은 세포독성이 없
었고, 계속되는 실험에서는 24 시간 처리가 아닌 2시간 전처리 만 하였다. Fisetin 또는 kaemferol를 2시간 처리했을 경우 세 포독성이 없다는 것을 확인하였으므로(결과 미제시) 계속되는 실험에서는 처리농도를 $100 \mu \mathrm{g} / \mathrm{mL}$ 까지 사용하였다.

$\mathrm{RBL}-2 \mathrm{H} 3$ 세포 내에서 $\operatorname{IgE}$ (항체)+DNP-HSA(항원) 복합 
체와 같은 다양한 자극에 반응하여 $\mathrm{ROS}$ 가 발생할 수 있다 (Chung 등, 2011; Han 등, 2011). Anthocyanins, fisetin 그리 고 kaemferol은 세포 내 ROS 소거 작용 및 강한 항산화작용 이 있는 것으로 알려져 있다(Chung 등, 2011; Chung 등, 2013; Chung 등, 2015). 그러나 IgE+DNP-HSA 복합체에 의 해 활성화 된 RBL-2H3 세포 내에서 kaemferol 처리에 의한 $\mathrm{ROS}$ 생성 억제 및 소거 작용에 대한 연구는 전무하다.

본 연구에서는 fisetin과 kaemferol 처리는 $\mathrm{IgE}$ 감작 후 항 원 노출에 의해 활성화 된 RBL-2H3 세포 내에서 증가된 $\mathrm{ROS}$ 를 두 물질 모두 농도 의존적으로 감소시켰는데(Fig. 6) 이와 같은 항산화 효과는 알레르기 질환 개선에 유익한 영향 력을 줄 수 있을 것으로 예상된다.

\section{Fisetin과 kaemferol이 $\boldsymbol{\beta}$-hexosaminidase 방출에 미치 는 영향}

$\mathrm{RBL}-2 \mathrm{H} 3$ 세포에 $\mathrm{IgE}$ 잠각 후 항원(DNP-HSA) 처리에 의 해 증가된 $\beta$-hexosaminidase 방출이 개발된 식물혼합물의 주 요 생리활성 물질인 fisetin과 kaemferol 처리에 의해 감소되 었다(Fig. 7). 양성대조군의 $\beta$-hexosaminidase 방출 퍼센트가 $100 \%$ 일 때 $100 \mu \mathrm{g} / \mathrm{mL}$ 의 fisetin과 kaemferol를 처리했을 때 $9.3 \%$ 와 $12.2 \%$ 였다(Fig. 7 ).

Kaempferol은 브로콜리, 사과, 생강 등 함유된 천연 플라 보노이드(Gong 등, 2012)이고, fisetin은 사과, 양파, 오이 등 에 함유된 플라보노이드(Shao 등, 2008)이므로 양파, 사과, 오이, 생강 및 브로콜리가 함유된 혼합물 추출물에서 이 두 물질이 주요 물질로 분석되었다. 수용성이 증가된 저분자 키

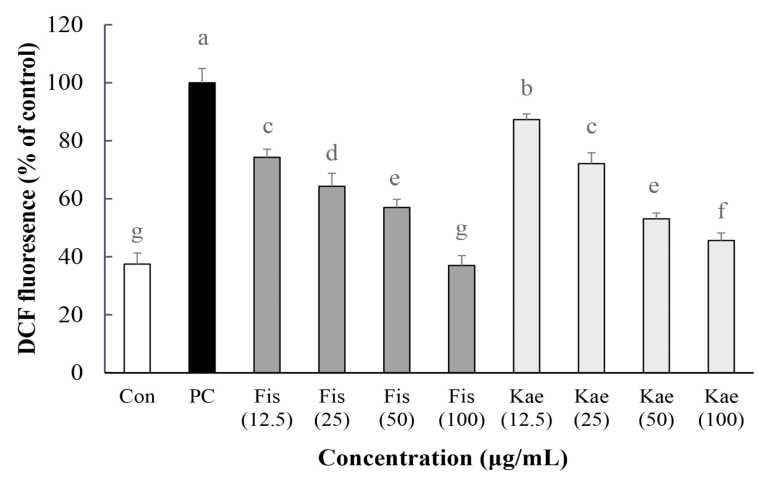

Fig. 6. Effects of fisetin and kaemferol on intracellular ROS production in IgE-antigen complex-stimulated RBL-2H3 cells.

IgE-sensitized RBL-2H3 cells were pretreated with fisetin (Fis) or kaemferol (Kae) for $2 \mathrm{~h}$ prior to exposure to DNP-HSA $(10 \mu \mathrm{g} / \mathrm{mL})$ for $2 \mathrm{~h}$. The ROS-mediated DCF oxidation was measured for intracellular ROS level detection. Con (control), without IgE + DNP-HSA and sample; PC (positive control), IgE + DNP-HSA. The values are expressed as mean $\pm \mathrm{SD}(\mathrm{n}=4)$; means with different letters significantly differ from each other $(p<0.05)$ as determined by Duncan's multiple range test.

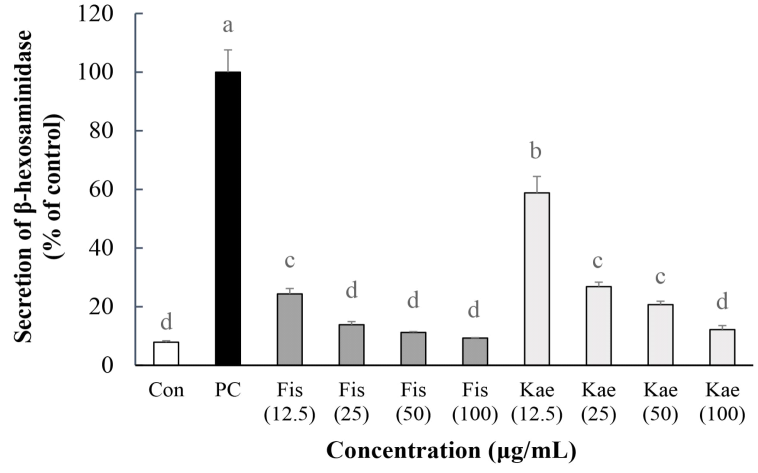

Fig. 7. Effects of fisetin and kaemferol on $\beta$-hexosaminidase release in IgE-antigen complex-stimulated RBL-2H3 cells.

IgE-sensitized RBL-2H3 cells were pretreated with fisetin (Fis) or kaemferol (Kae) for $2 \mathrm{~h}$ prior to exposure to DNP-HSA $(10 \mu \mathrm{g} / \mathrm{mL})$ for $2 \mathrm{~h}$. Con (control), without IgE + DNP-HSA and sample; PC (positive control), $\operatorname{IgE}+$ DNP-HSA. The values are expressed as mean $\pm \mathrm{SD}(\mathrm{n}=4)$; means with different letters significantly differ from each other $(\mathrm{p}<0.05)$ as determined by Duncan's multiple range test.

토산 올리고당은 $\mathrm{IgE}+\mathrm{DNP}-\mathrm{HSA}$ 복합체에 의해 활성화된 호 염기구에서 다량 분비되는 탈과립화를 억제하였고(Chung 등, 2012), fisetin은 비만세포 및 호염기성 세포에서 항알레 르기 효과가 있다는 것이 알려져 있다(Chung 등, 2013; Grosman, 1988). Kaempferol은 알레르기 천식 동물 모델에 서 항염증 효과가 있었고, $\operatorname{IgE}$ 함량을 감소시키는 것을 증명 함으로써 알레르기에 의한 천식을 억제할 수 있을 것이라는 연구보고가 있지만(Chung 등, 2015), 본 연구와 유사한 세포 모델에서 항알레르기 효과를 연구한 결과들에 대한 보고는 전무하다.

본 연구 결과, 개발된 혼합물에 함유된 주성분이 세포의 탈과립화를 억제하여 항알레르기 효과가 있을 것이라는 것을 알 수 있었으므로 개발된 혼합물은 알레르기 저감화 효과를 가진 제품 개발에 적합한 추출물이라는 것을 한번 더 증명하 였다.

IgE-항원 복합체에 의해 활성화된 RBL-2H3 세포에서 증 가된 $\beta$-hexosaminidase 방출 억제 효과가 가장 뛰어난 Mix 2 를 RBL-2H3 세포에 $250 \mu \mathrm{g} / \mathrm{mL}$ 처리했을 때 fisetin이 $0.0165 \mu \mathrm{g} / \mathrm{mL}$, kaempferol $0.0048 \mu \mathrm{g} / \mathrm{mL}$, isoquercitrin $0.3735 \mu \mathrm{g} / \mathrm{mL}$ 함유된 것으로 fisetin과 kaempferol를 각각 $\mathrm{RBL}-2 \mathrm{H} 3$ 를 처리한 가장 낮은 농도 $(12.5 \mu \mathrm{g} / \mathrm{mL})$ 보다 낮은 농도지만 $250 \mu \mathrm{g} / \mathrm{mL}$ Mix 2 처리가 $12.5 \mu \mathrm{g} / \mathrm{mL}$ Fis나 Kae를 각각 처리한 $\mathrm{RBL}-2 \mathrm{H} 3$ 세포에서보다 더 효과적으로 $\beta$ hesoxaminidase 분비를 억제시킨 것은 항알레르기 효과가 뛰 어난 fisetin, kaempferol, isoquercitrin 그리고 spiraeoside의 상승효과에 의한 것과 이들 물질 외에 추출물에 함유된 다른 생리활성 물질에 영향일 것으로 생각된다. 


\section{Fisetin과 kaemferol0이 IL-4, IL-13 및 TNF- $\alpha$ 생성에 미치는 영향}

$\mathrm{IgE}$-항원(DNP-HSA)에 의해 활성화된 RBL-2H3 세포 내 fisetin과 kaemferol 처리가 IL-4, IL-13 및 TNF- $\alpha$ 발현에 미 치는 영향은 Fig. 8 과 같다.

$\mathrm{IgE}$ 에 의해 감작된 RBL-2H3 세포에 DNA-HSA를 처리했 을 때 IL-4, IL-13 및 TNF- $\alpha$ 단백질 함량이 현저하게 증가하 였고, fisetin과 kaemferol 처리에 의해 현저하게 감소하였다. Fisetin 처리에 의한 IL-4와 TNF- $\alpha$ 단백질 함량 감소가 kaemferol 처리에 의한 감소보다 더 효과적이었다(Fig. 8).

안토시아닌, 다양한 플라보노이드, 키토산 올리고당 등 천 연소재들은 염증 및 알레르기 세포모델이나 동물모델에서 사 이토카인 생성을 억제함으로써 알레르기 관련 질환을 완화시 킬 수 있을 것이라는 보고들이 있고(Chung 등, 2011; Chung 등, 2012; Chung 등, 2013; Chung 등, 2015), 쑥에서 분리된 eupatlian과 jaceosidin 처리가 탈과립 및 알레르기 관련 사이 토카인(IL-4 그리고 TNF- $\alpha$ )의 생성을 감소함으로써 항알레 르기 효과가 있다고 보고하였다(Lee 등, 2007).

본 연구 결과, 양파, 사과, 오이, 생강 그리고 브로콜리로 개발한 혼합물들과 이들 혼합물에 함유된 주요 생리활성 물질 인 fisetin과 kaemferol은 $\beta$-hexosaminidase 방출 및 사이토카 인 생성을 현저하게 억제하였으므로 개발된 혼합물은 알레르 젠을 가진 식재료를 활용한 제품 개발에 알레르기 저감화 효 과를 유도하기 위해 사용할 수 있을 것으로 예측할 수 있었다.

\section{요 약}

Rat basophilic leukemia RBL-2H3 세포에서 IgE-항원 복 합체에 의해 자극된 알레르기 반응에 대한 양파, 사과, 오이, 생강, 브로콜리 혼합물들 및 이들에 함유된 생리활성 물질들 의 항알레르기 효과를 연구하였다. 세포 생존율, ROS 생성, $\beta$-hexosaminidase 방출, cytokines 생성은 각각 MTT 환원법, DCF-DA법, $\beta$-hexosaminidase법 그리고 ELISA법으로 분석 하였다. 양파, 사과, 오이, 생강, 브로콜리의 주정 추출물들은 $\mathrm{IgE}-$ 항원 복합체에 의해 자극된 RBL-2H3 세포에서 $\beta$ hexosaminidase의 방출을 억제하였다. 양파, 사과, 오이, 생 강, 브로콜리의 비율을 달리한 혼합물들(1,2 그리고 3)을 준 비하였다. 이들 혼합물의 추출물들 역시 IgE-항원 복합체 자 극에 의해 증가된 $\beta$-hexosaminidase의 방출을 억제하였다. $\mathrm{HPLC}$ 로 이들의 추출물들에 함유한 주요 생리 활성 화합물 들이 fisetin, kaempferol, isoquercitrin 그리고 spiraeoside이 라는 것을 확인하였다. Fisetin과 kaempferol은 IgE-항원 복 합체에 의해 자극된 RBL-2H3 세포에서 ROS와 $\beta$ - hexosaminidase 생성 증가를 농도 의존적으로 억제하였다. 더하여,
(A)

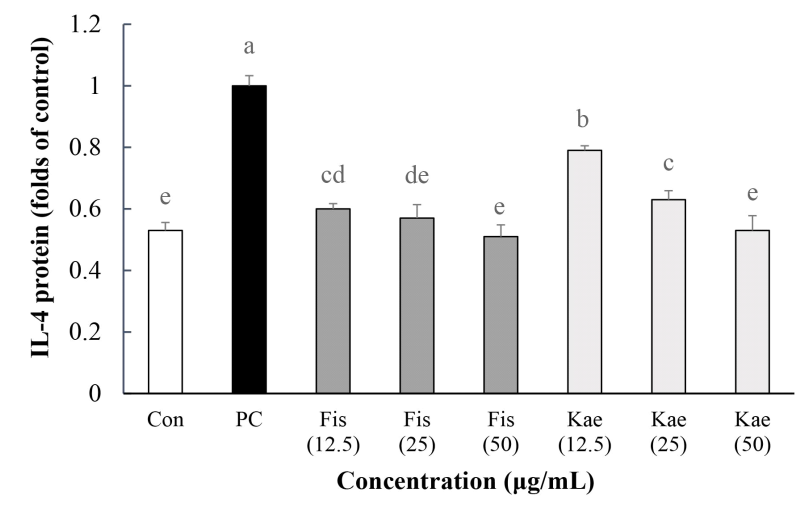

(B)

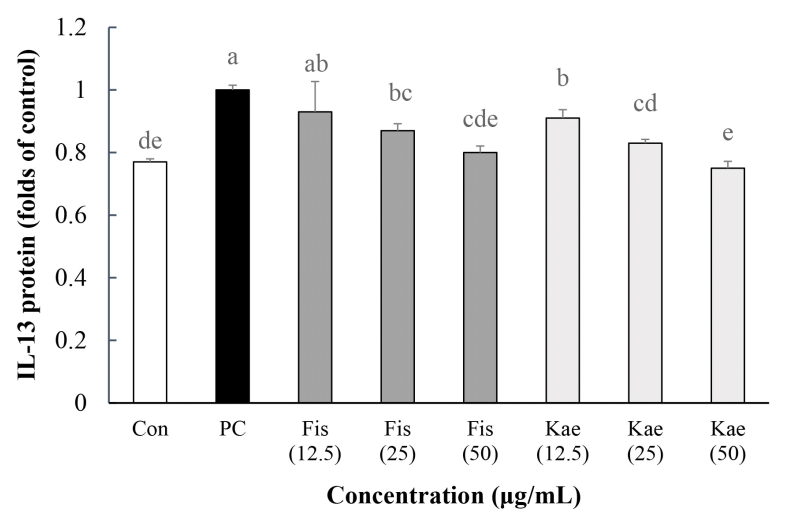

(C)

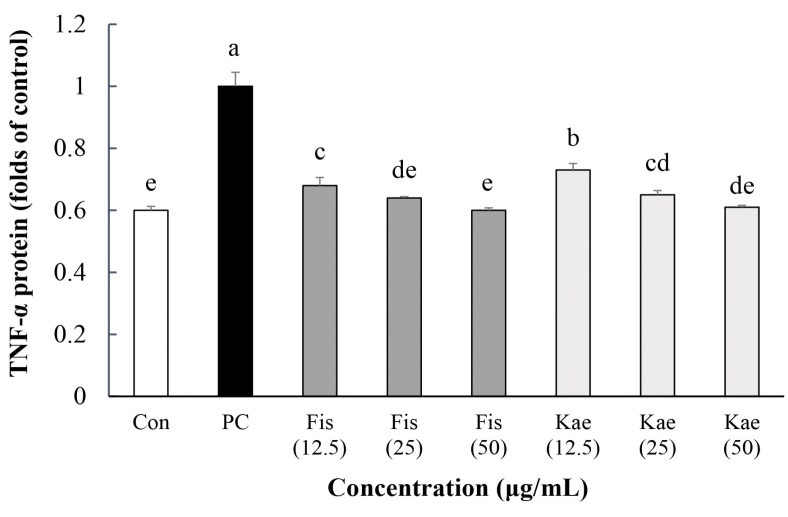

Fig. 8. Effects of fisetin and kaemferol on the IL-4, IL-5 and TNF$\alpha$ protein levels in IgE-antigen complex-stimulated RBL-2H3 cells. IgE-sensitized RBL-2H3 cells were pretreated with fisetin (Fis) or kaemferol (Kae) for $2 \mathrm{~h}$ prior to exposure to DNP-HSA $(10 \mu \mathrm{g} / \mathrm{mL})$ for $2 \mathrm{~h}$. Con (control), without IgE + DNP-HSA and sample; PC (positive control), IgE + DNP-HSA. The values are expressed as mean \pm SD $(n=4)$; means with different letters significantly differ from each other $(\mathrm{p}<0.05)$ as determined by Duncan's multiple range test.

fisetin과 kaempferol은 IL-4, IL-13 그리고 $\mathrm{TNF}-\alpha$ 와 같은 $\mathrm{IgE}$ 매개 전염증성 cytokines의 생성을 현저하게 약화시켰다. 더하여, Fisetin과 kaempferol을 함유한 혼합물들은 항알레르 
기 기능성 식품들 개발에 사용할 수도 있을 것으로 추정된다.

\section{감사의 글}

본 성과물은 중소벤처기업부에서 지원하는 "2020년도 지 역특화산업육성+(R\&D)-지역스타기업육성 사업(No. S28681 $21) "$ 의 연구수행으로 인한 결과물임을 밝힙니다.

\section{Conflict of interests}

The authors declare no potential conflict of interest.

\section{ORCID}

Mi Ja Chung https://orcid.org/0000-0003-0816-1354

\section{References}

Cha JY, Jeong JJ, Kim YT, Seo WS, Yang HJ, Kim JS, Lee YS. Detection of chemical characteristics in Hamcho (Salicornia herbacea L.) according to harvest periods. J Life Sci, 16, 683-690 (2006)

Choi HJ, Lee WS, Hwang SJ, Lee IJ, Shin DH, Kim HY, Kim KU. Changes in chemical compositions of green tea (Camellia sinensis L.) under the different extraction conditions. J Life Sci, 10, 202-209 (2000)

Chung MJ, Ha TJ, Choi HN, Lee JS, Park YI. Inhibitory effects of anthocyanins isolated from black soybean (Glycine $\max$ L.) seed coat on degranulation and cytokine generation in RBL-2H3 cells. J Korean Soc Food Sci Nutr, 40, 1662-1667 (2011)

Chung MJ, Park JK, Park YI. Anti-inflammatory effects of low-molecular weight chitosan oligosaccharides in IgE-antigen complex-stimulated RBL-2H3 cells and asthma model mice. Int Immunopharmacol, 12, 453-459 (2012)

Chung MJ, Sohng JK, Choi DJ, Park YI. Inhibitory effect of phloretin and biochanin A on IgE-mediated allergic responses in rat basophilic leukemia RBL-2H3 cells. Life Sci, 93, 401-408 (2013)

Gong JH, Shin DK, Han SY, Kim JL, Kang YH. Kaempferol suppresses eosinophil infiltration and airway inflammation in airway epithelial cells and in mice with allergic asthma. J Nutr, 142, 47-56 (2012)

Grosman N. Inhibitory effect of phloretin on histamin release from isolated rat mast cells. Agents Actions, 25, 284-290 (1988)

Han EH, Hwang YP, Kim HG, Park JH, Choi JH, Im JH, Khanal T, Park BH, Yang JH, Choi JM, Chun SS, Seo JK, Chung YC, Jeong HG. Ethyl acetate extract of Psidium guajava inhibits IgE-mediated allergic responses by blocking FceRI signaling. Food Chem Toxicol, 49, 100-108 (2011)

Hwang KA, Hwang YJ, Song J. Anti-allergic effect of Aster yomena on ovalbumin-sensitized mouse and RHL-2H3 cells via Th1/Th2 cytokine balance. J Funct Foods, 44, 1-8 (2018)

Jeong IS, Kim EH, Park SM, Chung MJ. Immunostimulatory effect of sweet potato peel-based plnat mixture on RAW264.7 macrophages. Korean J Food Preserv, 26, 828-836 (2019)

Kang WS, Jeong SM, Ryu SH, Xu X, Lee JE, Ahn DH. Anti-atopic effect of DNCB-induced mouse in Chondrus canaliculatus ethanol extracts. J Korean Soc Food Sci Nutr, 49, 653-658 (2020)

Kim JK, Seo YK, Park S, Park SA, Lim S, Lee S, Kwon O, Seo JK, Choi UK, Ryu SH, Suh PG. Spiraeoside inhibits mast cells activation and IgE-mediated allergic responses by suppressing phospholipase $\mathrm{C}-\gamma$-mediated signaling. Biochem Cell Biol, 93, 227-235 (2015)

Lee SH, Bae EA, Park EK, Shin YW, Baek NI, Han EJ, Chung HG, Kim DH. Inhibitory effect of eupatilin and jaceosidin isolated from Artemisia princeps in IgEinduced hypersensitivity. Int Immunopharmacol, 7, 1678-1684 (2007)

Leung DYM, Boguniewicz M, Howell MD, Nomura I, Hamid QA. New insights into atopic dermatitis. J Clin Invest, 113, 651-657 (2004)

Shao X, Bai N, He K, Ho CT, Yang CS, Sang S. Apple polyphenols, phloretin and phloridzin: New trapping agents of reactive dicarbonyl species. Chem Res Toxicol, 21, 2042-2050 (2008)

Wendeler M, Sandhoff K. Hexosaminidase assays. Glycoconjugate J, 26, 945-952 (2009) 